\title{
Urgent care practice in anorectal abscess. Still a pending task
} Manejo urgente de los abscesos perianales. Una tarea aún pendiente

\author{
Quetzalihuitl Arroyo-Martinez ${ }^{1,2 *}$, Carlos Gonzalez-de Pedro ${ }^{1}$ Eduardo Perea-del Pozo', \\ Sara Martinez-Nuñez ${ }^{1}$, Francisco J. Padillo-Ruiz', and Fernando De la Portilla-de Juan ${ }^{1}$ \\ ${ }^{1}$ Unit of General Surgery and Digestive System Clinical Management, Hospital Universitario Virgen del Rocío; ${ }^{2}$ Service of General Surgery and \\ Digestive System, Hospital Comarcal La Merced. Sevilla, Spain
}

\begin{abstract}
Aim: The aim of the study was to evaluate urgent care practice with regard to anorectal abscesses $(A A)$ in a tertiary-level referral hospital. Materials and methods: this was retrospective and unicentric study. Patients who underwent surgery for $A A$ between 2016 and 2017 were included in the study. Demographic variables were analyzed as well as the treatment performed, the need for hospitalization, use of antibiotics, and referral to the coloproctology outpatient department (COD). The recurrence risk factors were also evaluated. Results: A total of 220 evaluations under anesthesia were performed, corresponding to 190 patients, 129 males (mean age $46 \pm 14.9$ years). The most frequent treatment in the emergency department (ED) was simple drainage (75.8\%). Antibiotic therapy was prescribed in $62.9 \%$ of the cases. A total of $41.1 \%$ of the patients were referred to a specialized COD. The only risk factor associated with recurrence was the presence of an associated anal fistula. Conclusions: Anorectal abscesses are very frequent in the ED. There is great clinical variability regarding the taking of cultures, prescription of antibiotics, and referral criteria to a specialized coloproctology outpatient department, without clear impact of any of them on the recurrence of the abscess.
\end{abstract}

Key words: Anal abscess. Anorectal abscess. Anal fistula. Risk factor.

\section{Resumen}

Objetivo: Evaluar el manejo de los abscesos perianales por parte del servicio de cirugía de urgencias. Método: Estudio unicéntrico retrospectivo. Se incluyeron pacientes que requirieron manejo quirúrgico de abscesos perianales de 2016 a 2017. Se analizaron variables demográficas, tratamientos realizados, necesidad de ingreso hospitalario, uso de antibióticos y necesidad de derivación a la consulta externa de coloproctología. Así mismo, se evaluaron los factores relacionados con la recurrencia del absceso. Resultados: Durante el periodo de estudio se realizaron 220 exploraciones, correspondientes a 190 pacientes (129 hombres) con una edad media de $46 \pm 14.9$ años. El tratamiento quirúrgico más frecuentemente realizado fue el drenaje simple (75.8\%). Se prescribieron antibióticos en el $62.9 \%$ de los casos. El $41.1 \%$ de los pacientes fueron remitidos a consulta externa de coloproctología. El único factor de riesgo asociado a la recurrencia fue la presencia de una fístula perianal asociada. Conclusiones: Los abscesos perianales son frecuentes en los servicios de urgencias. Hay una gran variabilidad clínica en su manejo, sobre todo en lo relativo a la realización de cultivos, la prescripción de antibióticos y la derivación a unidades de coloproctología especializadas, sin que ninguna de estas medidas tenga un claro impacto en la recurrencia.

Palabras clave: Absceso anal. Absceso perianal. Fístula perianal. Factor de riesgo.

\footnotetext{
Correspondence:

*Quetzalihuitl Arroyo-Martínez

Avda Manuel Siurot, $\mathrm{s} / \mathrm{n}$

Date of reception: 28-11-2018

Cir Cir. 2020;88(6):690-697

C.P. 4101, Sevilla, Spain

Date of acceptance: $18-04-2020$

E -mail: quetzalihuit! @ hotmail.com

DOI: $10.24875 / \mathrm{CIRU} .20000926$

Contents available at PubMed

www.cirugiaycirujanos.com

0009-7411/@ 2020 Academia Mexicana de Cirugía. Published by Permanyer. This is an open access article under the terms of the CC BY-NC-ND license (http://creativecommons.org/licenses/by-nc-nd/4.0/).
} 


\section{Introduction}

The real incidence of anorectal abscesses and anal fistulas in emergency department (ED) is difficult, since many of them drain spontaneously or are drained in primary care services without any sequelae. It is estimated that $40 \%$ of patients with anorectal abscesses will develop an anal fistula during its evolution ${ }^{1-3}$. In Spain, the incidence of anal fistulae is around $1.04 / 10,000$ inhabitants/year $^{4}$, which corresponds to the general perception of its relatively low incidence, although it seems a little higher compared to other series that placed it around 0.86/10,000 inhabitants/year ${ }^{5}$. Anorectal infections are especially frequent in patients with Crohn disease, acquired immune deficiency syndrome, or immunosuppressed due to any other cause ${ }^{6}$.

Regarding the management of anorectal abscesses in the ED, there is great heterogeneity in the standards of clinical practice. Although the clinical guidelines for the management of anorectal abscesses and anal and rectovaginal fistulas have been recently published $^{7}$, the reality of daily practice is that the assessment of these patients, in a high percentage of cases, is performed by physicians without the necessary experience for its correct diagnosis and treatment ${ }^{8}$. The objective of this study is the evaluation of the treatment performed in patients with anorectal abscesses in the ED and its impact on disease recurrence.

\section{Methods}

We have retrospectively evaluated all patients with anorectal abscess diagnosed during one year. Those cases that required evaluation under anesthesia (EUA) were included. Patients undergoing evaluation without anesthesia, soft-tissue abscess different from the anorectal region and those with Fournier gangrene were excluded from the study. All patients provided informed consent, and the study was approved by the ethics committee.

Socio-demographic aspects, associated comorbidity, seasonality of the disease, as well as the type of treatment performed in the ED were analyzed.

We studied the type of antibiotic prescribed, the criteria for its prescription as well as for the taking of cultures. Patients were divided according to the sensitivity to the prescribed empirical antibiotic treatment, ranging from "sensitive," "resistant," or "indeterminate," being understood as "indeterminate" those cases, in which the sensitivity of the bacteria could not be determined (multiple flora) or did not have relevance given that an empirical antibiotic was not prescribed. The relationship between antibiotic sensitivity and the abscess recurrence was assessed.

Finally, we evaluated those patients referred to the specialized coloproctology outpatient department (COD) after abscess drainage in the ED. We analyzed general parameters (sex and age), associated comorbidity, referral criteria to specialized consultation, and presence of anal fistula compared with the previous existence of it in the emergency surgical exploration. To do this, a physical evaluation was performed, accompanied by an endoanal ultrasound to determine the type of fistula.

\section{Statistical analysis}

Qualitative and quantitative variables were analyzed. For the statistical analysis of the quantitative variables, we performed the Student's t-test and for qualitative variables, Pearson Chi-square test $\left(\chi^{2}\right)$. For the study of the risk factors involved in the recurrence of anorectal abscess, the absolute and relative odds ratio $(\mathrm{OR})$ was determined by logistic regression analysis, considering values of $p<0.05$ as statistically significant. Data were analyzed using SPSS ${ }^{\circledR}$ Statistics v.23 (SPSS Inc, Chicago IL, USA).

\section{Results}

During the period of study, 220 anorectal abscesses were diagnosed, corresponding to 190 patients (127 men, mean age 46.4 years \pm 14.9 ) (Fig. 1). Eighty-nine patients (46.8\%) had abscess recurrence, 63 (70.7\%) at the time of inclusion in this study.

Most patients had no significant medical history, 28 (14.7\%) were diabetic and $12(6.3 \%)$ had Crohn disease (Table 1). In terms of seasonality, most cases $(64 \%)$ occurred in the months of autumn and winter. The most frequent treatment performed in the ED was simple drainage $(75.8 \%)$, followed by drainage + seton placement (17.9\%). At the time of drainage, 66 patients $(34.7 \%)$ had an associated anal fistula. Cultures were taken in 26 patients (13.7\%) and 119 were prescribed antibiotics $(62.6 \%)$. Forty-one patients $(21.6 \%)$ required hospital admission, while $78(41.1 \%)$ were referred to our specialized COD.

\section{Microbiological analysis}

In this study and after analyzing different parameters, we failed to identify clear criteria, guidelines, or 


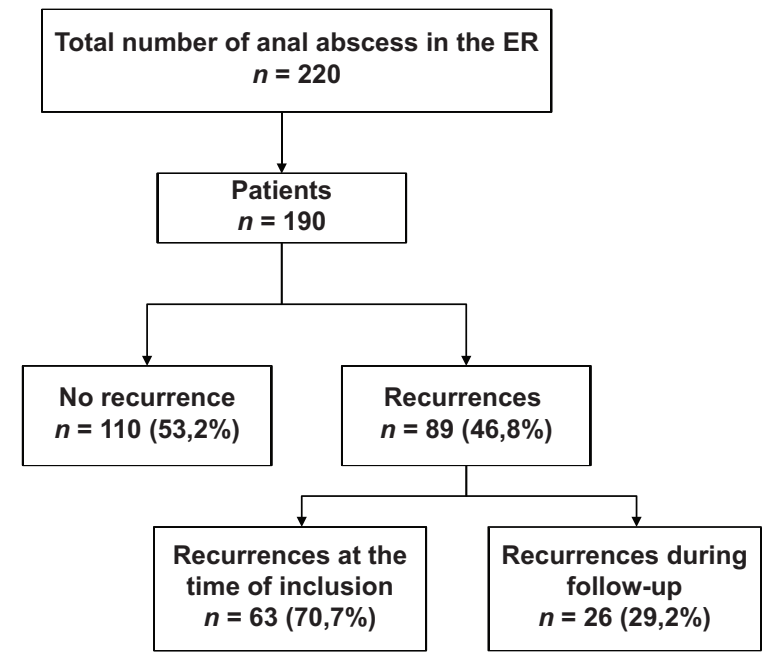

Figure 1. Flowchart of study patients. ER: emergency room.

standard operating procedures for microbiology cultures, except in those cases of antibiotic prescription or where hospitalization was indicated $(p=0.002$ and $p<0.001$, respectively) (Table 2). In cases, where empirical antibiotic therapy was prescribed, the most commonly used was amoxicillin/clavulanic acid (36\%).

In the microbiological analysis of the cultures obtained, the most frequent bacteria wer Escherichia coli (E. coli); however, up to 24 types of bacteria were cultured, mostly Gram-positive. Regarding the rate of recurrence of the abscesses, according to the microbiological sensitivity to the prescribed empirical antibiotic, it was $48.1 \%, 25 \%$, and $42.8 \%$ for "sensitive," "resistant," and "indeterminate," respectively. Most of the antibiotic resistance corresponded to the combination amoxicillin/clavulanic acid (Table 3).

\section{Factors related to recurrence of anorectal abscess}

Initially, we observed that the presence of Crohn disease $(\mathrm{OR}=6.26,95 \% \mathrm{Cl}, 1.33-29.4, \mathrm{P}=0.009)$ as well as an associated anal fistula (OR $=11.44,95 \%$ $\mathrm{Cl}, 5.47-23.9, \mathrm{P}=<0.001$ ) was related to abscess recurrence; however, after carrying out a unidimensional logistic regression model, we observed that the presence of an anal fistula is the only risk factor associated with recurrence $(\mathrm{OR}=11.21,95 \% \mathrm{Cl}, 5.28$ 23.79, $\mathrm{P}=<0.001$ ).

In patients whom an antibiotic was not prescribed, values of statistical significance were obtained as a protective factor against abscess recurrence (adjusted
Table 1. Socio-demographic characteristics of the study population

\begin{tabular}{|c|c|}
\hline Variables & $\mathrm{N}(\%)$ \\
\hline \multicolumn{2}{|l|}{ Sex } \\
\hline Male & $127(66.8)$ \\
\hline Female & $63(33.2)$ \\
\hline Mean age & $46.4 \pm 14.9(18-91)$ \\
\hline \multicolumn{2}{|l|}{ Comorbidity } \\
\hline None & 148 (77.9) \\
\hline $\mathrm{DM}$ & $28(14.7)$ \\
\hline Crohn disease & $12(6.3)$ \\
\hline $\mathrm{DM}+$ Crohn disease & $1(0.5)$ \\
\hline $\mathrm{AML}$ & $1(0.5)$ \\
\hline \multicolumn{2}{|l|}{ Seasonality } \\
\hline Autumn & $59(33.7)$ \\
\hline Winter & $50(30.3)$ \\
\hline Spring & $32(18.3)$ \\
\hline Summer & $31(17.7)$ \\
\hline \multicolumn{2}{|c|}{ Type of treatment performed in the ER } \\
\hline Drainage alone & $144(75.8)$ \\
\hline Drainage + Pezzer catheter & $6(3.2)$ \\
\hline Drainage + Penrose drain & $3(1.6)$ \\
\hline Drainage + Seton & $34(17.9)$ \\
\hline Fistulectomy & $1(0.5)$ \\
\hline Fistulotomy & $1(0.5)$ \\
\hline None & $1(0.5)$ \\
\hline \multicolumn{2}{|l|}{ Microbiological cultures } \\
\hline No & $164(86.3)$ \\
\hline Yes & $26(13.7)$ \\
\hline \multicolumn{2}{|l|}{ Antibiotic } \\
\hline No & $70(36.8)$ \\
\hline Yes & $119(62.6)$ \\
\hline \multicolumn{2}{|l|}{ Anal abscess recurrence } \\
\hline No & $101(53.2)$ \\
\hline Yes & $89(46.8)$ \\
\hline \multicolumn{2}{|l|}{ Need for hospital admission } \\
\hline No & $149(78.4)$ \\
\hline Yes & $41(21.6)$ \\
\hline \multicolumn{2}{|c|}{$\begin{array}{l}\text { Need for referral to coloproctology outpatient } \\
\text { department }\end{array}$} \\
\hline No & $112(58.9)$ \\
\hline Yes & $78(41.1)$ \\
\hline \multicolumn{2}{|l|}{ Associated anal fistula } \\
\hline No & $124(65.3)$ \\
\hline Yes & $66(34.7)$ \\
\hline
\end{tabular}

$\mathrm{OR}=2.59,95 \% \mathrm{Cl}, 1.21-5.05, \mathrm{p}=0.013)$. However, this value should be taken with caution, given that an alternative interpretation, and perhaps more adjusted to reality, could be that patients with recurrence of anorectal abscess received empirical antibiotic treatment in a greater proportion (Table 4). 
Table 2. Observed criteria for the taking of microbiological cultures

\begin{tabular}{|c|c|c|c|}
\hline \multirow[t]{2}{*}{ Variables } & \multicolumn{2}{|c|}{ Microbiological culture } & \multirow[t]{2}{*}{$p$} \\
\hline & No & Yes & \\
\hline \multicolumn{4}{|l|}{ Sex } \\
\hline Male & 109 & 18 & \multirow[t]{2}{*}{0.781} \\
\hline Female & 55 & 8 & \\
\hline Age (years) & $46.2 \pm 14.8$ & $47.4 \pm 15.9$ & 0.721 \\
\hline \multicolumn{4}{|l|}{ Comorbidity } \\
\hline None & 130 & 18 & \multirow[t]{5}{*}{0.076} \\
\hline DM & 22 & 6 & \\
\hline Crohn disease & 11 & 1 & \\
\hline $\mathrm{DM}+$ Crohn disease & 1 & 0 & \\
\hline $\mathrm{AML}$ & 0 & 1 & \\
\hline \multicolumn{4}{|l|}{ Anal fistula } \\
\hline No & 106 & 18 & \multirow[t]{2}{*}{0.647} \\
\hline Yes & 58 & 8 & \\
\hline \multicolumn{4}{|l|}{ Recurrence } \\
\hline No & 89 & 12 & \multirow[t]{2}{*}{0.441} \\
\hline Yes & 75 & 14 & \\
\hline \multicolumn{4}{|l|}{ Antibiotic prescription } \\
\hline No & 66 & 5 & \multirow[t]{2}{*}{0.002} \\
\hline Yes & 98 & 21 & \\
\hline \multicolumn{4}{|l|}{ Need for hospitalization } \\
\hline No & 137 & 12 & \multirow[t]{2}{*}{$<0.001$} \\
\hline Yes & 27 & 14 & \\
\hline \multicolumn{4}{|c|}{ Need for specialized consultation } \\
\hline No & 96 & 16 & \multirow[t]{2}{*}{0.773} \\
\hline Yes & 68 & 10 & \\
\hline
\end{tabular}

\section{Follow-up of patients referred to specialized COD}

A total of 78 patients $(41.1 \%)$ were referred to specialized consultation, most of them $(74.4 \%)$ had no significant medical history. All were clinically evaluated and 3D endoanal ultrasound was performed in 65 patients $(83 \%)$.

The analysis of referral criteria to specialized consultation showed that most of cases were patients with recurrence of anorectal abscess with or without associated anal fistula (79.5\%). Nine (11.5\%) patients presented only anal fistula as derivation criteria and one $(1.2 \%)$ due to medical history of Crohn disease. No clear referral criteria were found in six patients (7.6\%).

Regarding the presence of anal fistulas, of the 66 patients in whom they were diagnosed in the emergency room, $55(83.3 \%)$ were referred to the specialized consultation for this reason. On arrival at the consultation, the fistula had disappeared in 29 $(52.8 \%)$ patients. Of the patients without an anal fistula objectified in the emergency room exploration, it was developed on arrival to the specialized coloproctology consultation in 14 cases $(60.8 \%)$; most of these patients had been referred under the indication of recurrent anorectal abscess. Transsphincteric fistula was the most frequently diagnosed (65\%) (Fig. 2).

\section{Discussion}

Surgical treatment of anorectal abscesses is a frequent surgical emergency in ED. In our case is second only to acute appendicitis for EUA. However, its approach continues to be subject to great variability ${ }^{7,9-11}$, not only from one hospital to another but also among professionals of the same hospital. As mentioned by Malik et al. in their work ${ }^{8}$, the treatment of anorectal abscesses, in the great majority of cases, is left to less experienced physicians (general surgery residents with little or no experience and young attending surgeons) with limited capacity for diagnosing associated complications or for the screening of associated fistulas.

One of the observations that we do share with most studies is that anorectal abscesses mainly affect the middle-aged male population. Although the exact causes of this association are still unknown, it is possible that it may reside in anatomical differences of the anal glands or that hormonal factors, not fully known, may be involved. We also observed that most cases $(64 \%)$ occur in the autumn-winter period. This situation, although it lacks clinical relevance, represents the opposite that would be expected in a hospital with very hot summers where sweating is profuse and moisture/maceration of anal and anorectal tissue is the norm. It is intuitive that, according to this observation, the development of anorectal abscesses depends more on intrinsic factors than on those related to the environment.

As in the majority of published articles, the most frequent surgical treatment performed in the ED was simple drainage followed by drainage + seton placement. Emergency fistulotomy simultaneous to the drainage of the abscess was performed in only $0.5 \%$ of the cases. Although there is a systematic review that advocates its implementation in specific cases (simple fistulas with a high risk of recurrence $)^{12}$, it seems that seton placement may be an equally effective procedure without the added risk of fecal incontinence ${ }^{13-15}$. 
Cirugía y Cirujanos. 2020;88(6)

Table 3. Microbiological characteristics of the cultures obtained in patients with perianal abscess

\begin{tabular}{|c|c|c|c|c|c|c|}
\hline Type of bacteria & $\begin{array}{l}\text { Microbiological } \\
\text { characteristics }\end{array}$ & Frequency & Empirical antibiotic prescribed & $\begin{array}{l}\text { Sensitive } \\
\text { (yes/no) }\end{array}$ & $\begin{array}{l}\text { Recurrence } \\
\text { (yes/no) }\end{array}$ & $\begin{array}{c}\% \text { of } \\
\text { recurrences }\end{array}$ \\
\hline $\begin{array}{l}\text { Enterococcus } \\
\text { faecium }\end{array}$ & $\begin{array}{l}\text { Gram }(+) / \text { facultative } \\
\text { anaerobic }\end{array}$ & 2 & $\begin{array}{l}\text { Linezolid/Cefixime (1)/Cipro + } \\
\text { Metro (1) }\end{array}$ & $\begin{array}{l}\text { Yes }(L+C) / \\
\text { No }(C+M)\end{array}$ & $\begin{array}{l}\text { Yes (1) } \\
\text { /No (1) }\end{array}$ & $27 / 13=48.1 \%$ \\
\hline $\begin{array}{l}\text { Bacteroides } \\
\text { uniformis }\end{array}$ & Gram (-)/anaerobic & 1 & Cipro + Metro & & Yes & \\
\hline $\begin{array}{l}\text { Actinomyces } \\
\text { turicensis }\end{array}$ & Gram (+)/anaerobic & 1 & Cipro + Metro & Yes & Yes & \\
\hline Clostridium difficile & Gram (+)/anaerobic & 1 & Vancomycin & Yes & Exitus & \\
\hline Escherichia coli & $\begin{array}{l}\text { Gram (-)/facultative } \\
\text { anaerobic }\end{array}$ & 10 & $\begin{array}{l}\text { Amox/Clav (5); Cipro + Metro (2); } \\
\text { None (2); Linezolid + Cefixime (1) }\end{array}$ & Yes & $\begin{array}{l}\text { Yes (5)/ } \\
\text { No (5) }\end{array}$ & \\
\hline $\begin{array}{l}\text { Streptococcus } \\
\text { anginosus }\end{array}$ & $\begin{array}{l}\text { Gram (+)/facultative } \\
\text { anaerobic }\end{array}$ & 1 & Amox/Clav & Yes & No & \\
\hline $\begin{array}{l}\text { Klebsiella } \\
\text { pneumoniae }\end{array}$ & $\begin{array}{l}\text { Gram (-)/encapsulated } \\
\text { anaerobic }\end{array}$ & 1 & Cipro + Metro & Yes & Yes & \\
\hline $\begin{array}{l}\text { Peptostreptococcus } \\
\text { harei }\end{array}$ & Gram (+)/anaerobic & 1 & Cipro + Metro & Yes & No & \\
\hline $\begin{array}{l}\text { Staphylococcus } \\
\text { aureus }\end{array}$ & $\begin{array}{l}\text { Gram }(+) / \text { facultative } \\
\text { anaerobic }\end{array}$ & 2 & Amox/Clav (1)/Cipro + Metro (1) & Yes & Yes (2) & \\
\hline Bacteroides fragilis & Gram (-)/anaerobic & 2 & Amox/Clav (2) & Yes & No (2) & \\
\hline $\begin{array}{l}\text { Bacteroides } \\
\text { thetaiotaomicron }\end{array}$ & Gram (-)/anaerobic & 1 & Amox/Clav & Yes & No & \\
\hline Prevotella bivia & Gram (-)/anaerobic & 1 & Cipro + Metro & Yes & Yes & \\
\hline $\begin{array}{l}\text { Peptostreptococcus } \\
\text { anaerobius }\end{array}$ & Gram (+)/anaerobic & 1 & Cipro + Metro & Yes & No & \\
\hline Propebela bergensis & Gram (+)/anaerobic & 1 & Cipro + Metro & Yes & No & \\
\hline Bacteroides ovatus & Gram (-)/anaerobic & 1 & Amox/Clav & Yes & Yes & \\
\hline $\begin{array}{l}\text { Pseudomonas } \\
\text { aeruginosa }\end{array}$ & Gram (-)/aerobic & 2 & Amox/Clav (2) & No (2) & $\begin{array}{l}\text { Yes (1) } \\
\text { /No (1) }\end{array}$ & $7 / 3=42.8 \%$ \\
\hline Candida & Fungi & 1 & Cipro + Metro & No & Yes & \\
\hline $\begin{array}{l}\text { Streptococcus } \\
\text { constellatus }\end{array}$ & $\begin{array}{l}\text { Gram }(+) / \text { facultative } \\
\text { anaerobic }\end{array}$ & 1 & Amox/Clav & No & No & \\
\hline Streptococcus oralis & Gram (+)/anaerobic & 1 & Amox/Clav & No & No & \\
\hline $\begin{array}{l}\text { Streptococcus } \\
\text { gallolyticus }\end{array}$ & Gram (+)/anaerobic & 1 & Amox/Clav & No & Yes & \\
\hline $\begin{array}{l}\text { Enterococcus } \\
\text { faecalis }\end{array}$ & $\begin{array}{l}\text { Gram }(+) / \text { catalase }(-) / \\
\text { anaerobic }\end{array}$ & 1 & Amox/Clav & No & No & \\
\hline $\begin{array}{l}\text { Streptococcus } \\
\text { intermedius }\end{array}$ & Gram (+)/anaerobic & 1 & None & $\mathrm{N} / \mathrm{A}$ & No & $8 / 2=25 \%$ \\
\hline Parvimonas micra & Gram (+)/anaerobic & 1 & None & $N / A$ & No & \\
\hline $\begin{array}{l}\text { Staphylococcus } \\
\text { Lugdunensis }\end{array}$ & $\begin{array}{l}\text { Gram (+)/Coagulase } \\
(-) / \text { facultative anaerobic }\end{array}$ & 1 & None & $\mathrm{N} / \mathrm{A}$ & No & \\
\hline $\begin{array}{l}\text { Fusobacterium } \\
\text { nucleatum }\end{array}$ & Gram (-)/anaerobic & 1 & None & $\mathrm{N} / \mathrm{A}$ & No & \\
\hline Multiple flora & $\mathrm{N} / \mathrm{A}$ & 2 & Amox/Clav & $\mathrm{N} / \mathrm{A}$ & Yes (2) & \\
\hline Negative & $\mathrm{N} / \mathrm{A}$ & 2 & Amox/Clav & $N / A$ & No (2) & \\
\hline Total & & 25 & & $\begin{array}{l}\text { Yes (15), No } \\
\text { (8), N/A (6) }\end{array}$ & Yes (18) /No ( & 23)/Exitus (1) \\
\hline
\end{tabular}


Table 4. Factors related to recurrence of perianal abscess. Odds ratio adjusted to univariate logistic regression

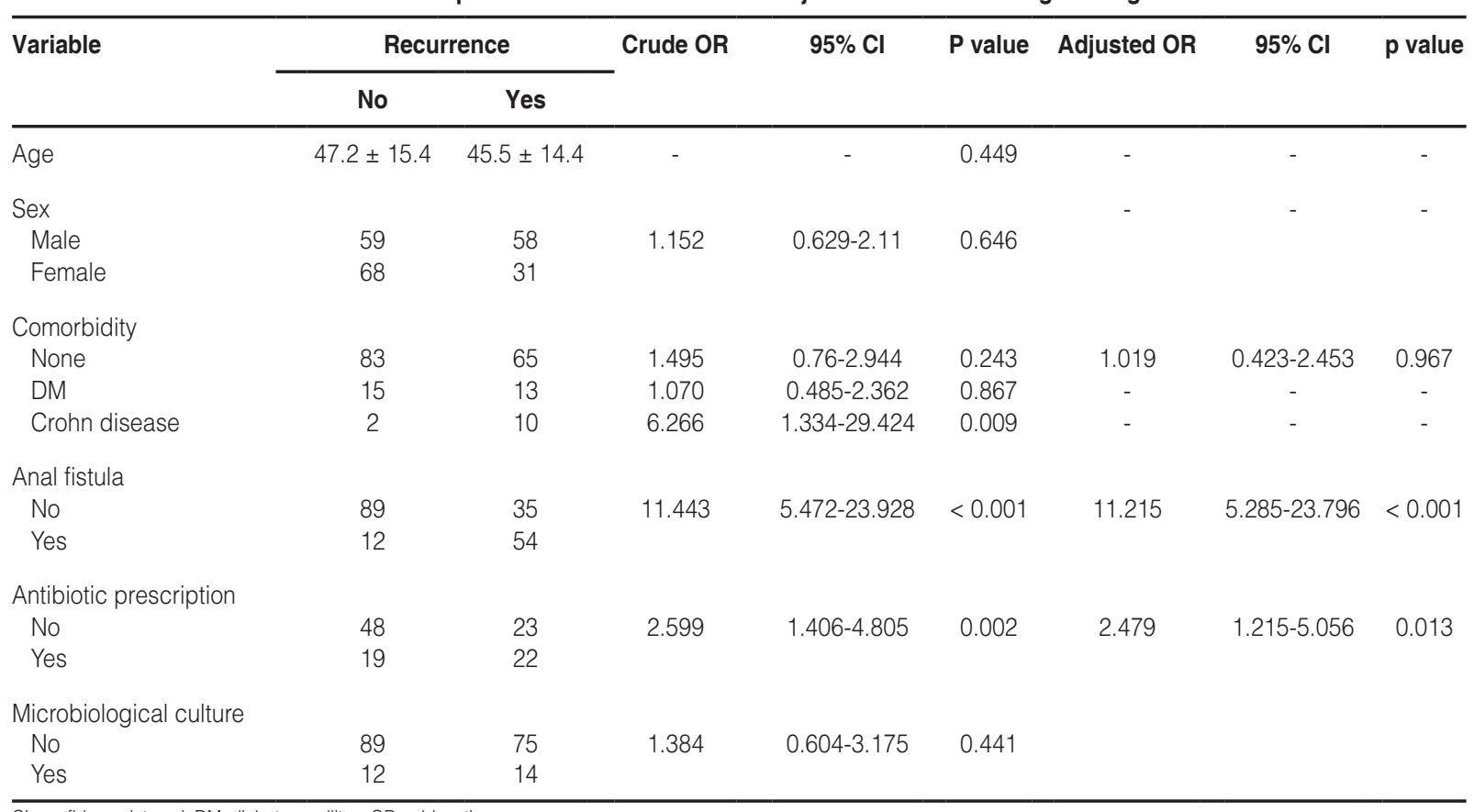

Cl: confidence interval; DM: diabetes mellitus; OR: odds ratio.

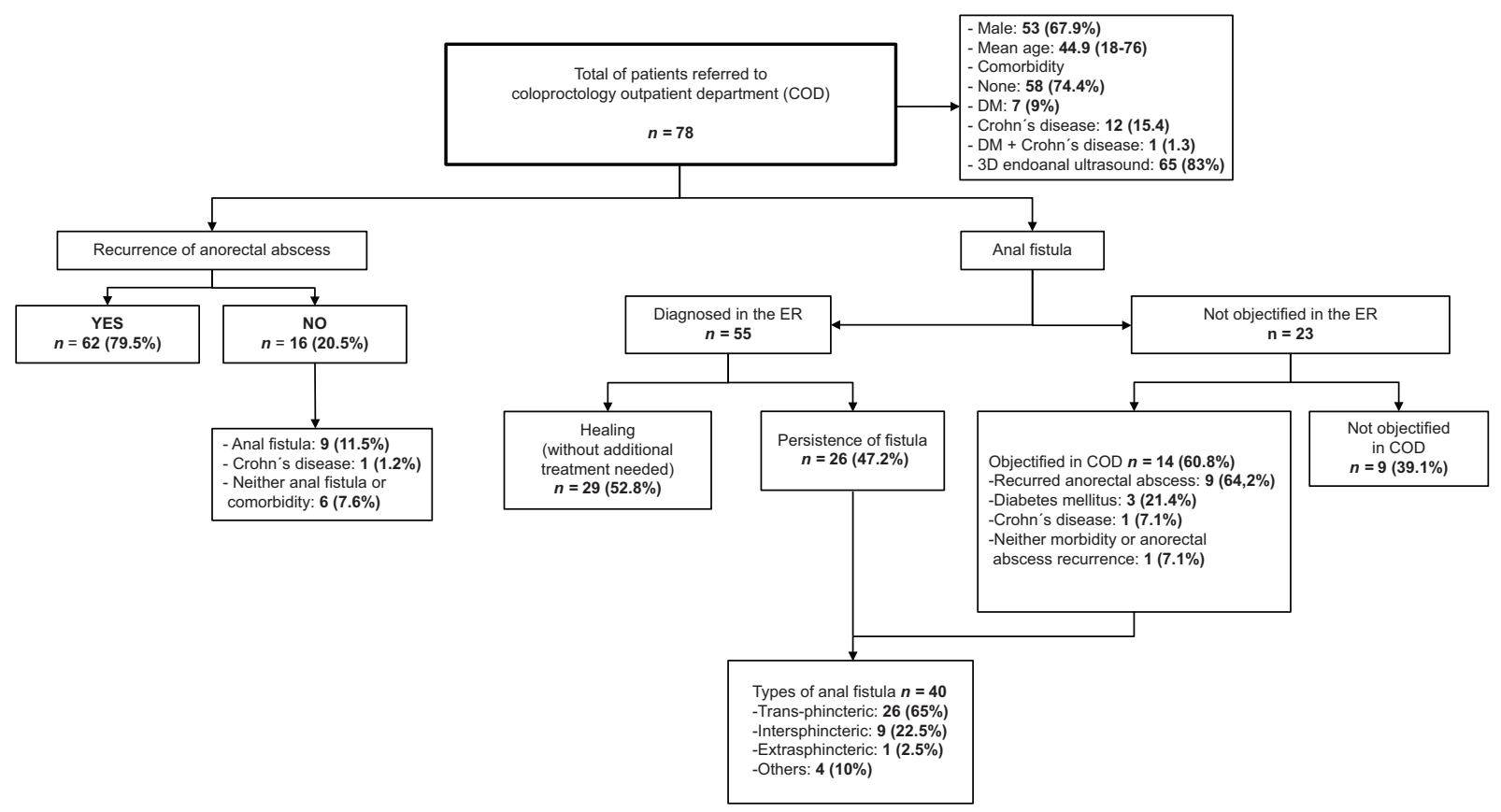

Figure 2. Detailed flowchart of patients referred to specialized COD. Results are shown in absolute numbers and percentage (\%). COD: coloproctology outpatient department; DM: diabetes mellitus; ER: emergency room.

Our study shows significantly higher rates of microbiological cultures and prescription of antibiotics than international standards, guidelines, and recommendations. We did not objectify clear criteria for the prescription of antibiotics or for the taking of cultures and, what is most important, neither the taking of cultures nor antibiotics significantly affected the recurrence rate of anal abscess. Even when the sensitivity of the bacteria to the empiric antibiotic treatment was confirmed by antibiogram, there were no lower anal 
abscess recurrence rates compared to when the bacterium was resistant. As mentioned by Leung et al. ${ }^{16}$, one of the main problems in taking cultures is that, in many cases, as they are outpatients without further follow-up, there is no physician in charge of reviewing the cultures and performing a targeted treatment, if needed. Therefore, based both on our results and in previous studies ${ }^{3,13,17,18}$, we support the recommendation to reserve the use of antibiotics for patients with anorectal abscesses and important cellulitis, signs of systemic disease, and/or in cases of immunosuppression. We also believe it is convenient to take cultures only in selected patients (persistent abscess with poor wound healing and/or suspected infection with methicillin-resistant Staphylococcus aureus [MRSA] or Pseudomonas). In the present study, of the 24 different types of bacteria and fungi isolated, we did not have any patient with MRSA but did find two cases of Pseudomonas infection. The majority of the observed antibiotic resistance corresponded to the group of beta-lactams + clavulanic acid.

Regarding the referral criteria to the specialized COD, we did not objectify any clear referral criteria in $7.6 \%$ of the cases. We believe that this value, although low compared to the total of treated and referred patients, could be easily improved, as it only implies giving greater responsibility to experienced surgeons and physicians in the diagnosis and treatment of anorectal abscesses.

With respect to the presence and development of anal fistulas in patients with anorectal abscesses, it has been classically established that it is present initially or develops later in $26-37 \%$ of cases ${ }^{2,19,20}$. In the present study, higher values were obtained $(50-60 \%)$. It is worth noting that about half of the fistulas diagnosed in the emergency room present spontaneous healing once the abscess is drained, without the need for additional treatments. However, on the other hand, there is a large percentage of patients (approximately $60 \%$ ) who can develop it after anal abscess is treated in their acute form, especially in cases of abscess recurrence or immunosuppression (lymphoma, diabetes mellitus, and/or inflammatory bowel disease).

In this study and after specific complementary tests performed in specialized, the transsphincteric fistula was the most frequently diagnosed in about $65 \%$ of cases. Given that so far there is no gold standard treatment for this type of anal fistula, we share the consideration of Soliman et al. ${ }^{21}$ that this is a type of fistula whose management is complex and sometimes with disastrous consequences; therefore, its assessment, treatment, and follow-up should be carried out in thirdlevel reference units, with extensive experience for the treatment of this complex pathology.

\section{Conclusions}

There is great variability regarding the management and treatment of anorectal abscesses in the ED. Simple drainage \pm seton placement represents the most recommended treatment. Systematized prescription of antibiotics and taking of cultures should be avoided, except in selected cases. It is important to design specific clinical pathways adapted to the needs and microbiological characteristics of each region, to optimize the management of patients with anorectal abscesses with or without anal fistula. With regard to anal fistulas, simple abscess drainage can be curative in more than half of the cases. Consultation to the specialized COD is recommended in cases of recurrent anal abscesses, anal fistulas, and immunosuppressed patients, given its increased risk of chronic anal fistula. We can conclude that the optimal management of anal abscess in ED is still a pending task. A proper diagnosis and treatment both in the ED and in specialized outpatient consultation, will reduce antibiotic resistance, preventing annoying, unnecessary and expensive proceedings to the patient, as well as avoid additional costs for the National Health System.

\section{Conflicts of interest}

The authors declare have no conflicts of interest.

\section{Ethical disclosures}

Protection of human and animal subjects. The authors declare that no experiments were performed on humans or animals for this study.

Confidentiality of data. The authors declare that they have followed the protocols of their work center on the publication of patient data.

Right to privacy and informed consent. The authors declare that no patient data appear in this article.

\section{References}

1. Hamadani A, Haigh PI, Liu IL, Abbas MA. Who is at risk for developing chronic anal fistula or recurrent anal sepsis after initial perianal abscess? Dis Colon Rectum. 2009;52:217-21.

2. Henrichsen S, Christiansen J. Incidence of fistula-in-ano complicating anorectal sepsis: a prospective study. Br J Surg. 1986;73:371-2. 
3. Vasilevsky CA, Gordon PH. The incidence of recurrent abscesses or fistula-in-ano following anorectal suppuration. Dis Colon Rectum. 1984;27:126-30.

4. Zanotti C, Martinez-Puente C, Pascual I, Pascual M, Herreros D, García-Olmo D. An assessment of the incidence of fistula-in-ano in four countries of the European Union. Int J Colorectal Dis. 2007;22:1459-62.

5. Sainio P. Fistula-in-ano in a defined population. Incidence and epidemiological aspects. Ann Chir Gynaecol. 1984;73:219-24.

6. Grace RH. The management of acute anorectal sepsis. Ann R Coll Surg Engl. 1990;72:160-2.

7. Vogel JD, Johnson EK, Morris AM, Paquette IM, Saclarides TJ, Feingold DL, et al. Clinical practice guideline for the management of anorectal abscess, fistula-in-ano, and rectovaginal fistula. Dis Colon Rectum. 2016;59:1117-33.

8. Malik A, Hall D, Devaney R, Sylvester H, Yalamarthi S. The impact of specialist experience in the surgical management of perianal abscesses. Int J Surg. 2011;9:475-7.

9. Whiteford MH, Kilkenny J, Hyman N, Buie WD, Cohen J, Orsay C, et al. Practice parameters for the treatment of perianal abscess and fistula-in-ano (revised). Dis Colon Rectum. 2005;48:1337-42.

10. Ommer A, Herold A, Berg E, Fürst A, Post S, Ruppert R, et al. German S3 guidelines: anal abscess and fistula (second revised version). Langenbecks Arch Surg. 2017;402:191-201.

11. Steele SR, Kumar R, Feingold DL, Rafferty JL, Buie WD, Standards Practice Task Force of the American Society of Colon and Rectal Surgeons. Practice parameters for the management of perianal abscess and fistula-in-ano. Dis Colon Rectum. 2011;54:1465-74.
12. Malik Al, Nelson RL, Tou S. Incision and drainage of perianal abscess with or without treatment of anal fistula. In: Malik Al, editor. Cochrane Database of Systematic Reviews. Chichester, UK: John Wiley and Sons, Ltd.; 2010. p. CD006827.

13. Abcarian H. Anorectal infection: abscess-fistula. Clin Colon Rectal Surg. 2011;24:14-21.

14. Schouten WR, van Vroonhoven TJ. Treatment of anorectal abscess with or without primary fistulectomy. Results of a prospective randomized trial. Dis Colon Rectum. 1991;34:60-3.

15. Oliver I, Lacueva FJ, Vicente FP, Arroyo A, Ferrer R, Cansado P, et al. Randomized clinical trial comparing simple drainage of anorectal abscess with and without fistula track treatment. Int J Colorectal Dis. 2003;18:107-10.

16. Leung E, McArdle K, Yazbek-Hanna M. Pus swabs in incision and drainage of perianal abscesses: what is the point? World J Surg. 2009;33:2448-51.

17. Llera JL, Levy RC. Treatment of cutaneous abscess: a double-blind clinical study. Ann Emerg Med. 1985;14:15-9.

18. Sözener U, Gedik E, Aslar AK, Ergun H, Elhan AH, Memikoğlu O, et al. Does adjuvant antibiotic treatment after drainage of anorectal abscess prevent development of anal fistulas? A randomized, placebo-controlled, double-blind, multicenter study. Dis Colon Rectum. 2011;54:923-9.

19. Read DR, Abcarian H. A prospective survey of 474 patients with anorectal abscess. Dis Colon Rectum. 1979;22:566-8.

20. Nelson R. Anorectal abscess fistula: what do we know? Surg Clin North Am. 2002;82:1139-51.

21. Soliman F, Sturgeon G, Hargest R. Revisiting an ancient treatment for transphincteric fistula-in-ano there is nothing new under the sun ecclesiastes 1v9. J R Soc Med. 2015;108:482-9. 